\title{
Precariousness and call centre work: Operators' perceptions in Portugal and Brazil
}

European Journal of Industrial Relations 2018, Vol. 24(3) 243-259

(C) The Author(s) 2017

Article reuse guidelines: sagepub.com/journals-permissions DOI: $10.1177 / 0959680117736626$ journals.sagepub.com/home/ejd

๑SAGE

\section{Hermes Augusto Costa \\ Universidade de Coimbra, Portugal}

\section{Elizardo Scarpati Costa}

Universidade Federal do Rio Grande, Brazil

\begin{abstract}
We present comparative research on operators' perceptions of the work process in two telecommunications call centres, one in Portugal and the other in Brazil. We argue that, despite the different pace of economic performance in recent years in Portugal and Brazil, there is a common trend towards casualization. Despite differences between the two call centres, both case studies show a process that imposes standardized behaviour. By exploring the subjective perceptions of call centre operators, we contribute to the 'pessimistic' (but probably more realistic) strand of literature on call centre work.
\end{abstract}

\section{Keywords}

Brazil, call centres, operators' perceptions, Portugal, precariousness

\section{Introduction}

Economic globalization generates opportunities for consumption (Du Gay, 1996) that do not correspond to those that exist in the field of production. The world of work in general and labour relations in particular seem increasingly marked by precarious employment, although on occasion, political and business discourse on the alleged virtues of labour flexibility ignores the work situations that are harmful to those who do the working. This article looks into one of these contemporary forms of work, call centre work, in the Portuguese and Brazilian contexts.

\section{Corresponding author:}

Hermes Augusto Costa, Faculdade de Economia da Universidade de Coimbra, Avenida Dias da Silva I65, 3004-5I2, Coimbra, Portugal.

Email: hermes@fe.uc.pt 
We first offer a brief overview of the forms of precarious employment currently found in the labour markets of both countries, so as to convey a sense of the many shapes of work today.

There has been a reduction in the traditional, industrial working class. At the same time, however, a significant subproletarization of labour occurred as a result of a wide variety of forms of work - part-time, precarious, informal, outsourced, etc. Work therefore became significantly heterogeneous, complex and fragmented. (Antunes, 1999: 209)

Second, to complement this general discussion, we provide a brief review of the literature on call centres. We distinguish between fatalistic and utopian perspectives. Fatalistic analyses emphasize the disruptive conditions that affect operators in their day-to-day work. Utopian analyses, on the other hand, perceive opportunities for upskilling and autonomy.

The third part presents the findings of our empirical research in call centres in both countries, describing the impact of precariousness on the work performed by telephone answering operators and the reconfiguration of labour relations in this sector. We explore the social and occupational identities of workers, the work environment and involvement in union activities.

Despite the different economic dynamics in recent years in Portugal and Brazil, the trend towards casualization is a typical feature of contemporary capitalism and occurs in both call centres. Despite differences between the two call centres, both case studies show little support for the 'utopian' view. Rather, call centre jobs seem to involve 'low road' processes of standardized behaviour (Kovács, 2005).

\section{Meanings and modalities of precarious employment in Portugal and Brazil}

While the meaning of 'precariousness' varies according to national definitions and legal frameworks, from a sociological point of view, one may say that precariousness involves subjective experiences, processes of social estrangement (Cingolani, 2005), 'the new poverty' and 'social disqualification' (Paugam, 2013), lack of social protection and loss of the standard employment relationship (Hewison, 2016). In this light, discontinuity (in terms of working hours, job tasks and employment status) and low incomes or impoverishment are two major characteristics (Cingolani, 2005; Soeiro, 2015).

Standing $(2009,2011)$ writes of the growth of a 'precariat', comprising those who keep moving from one unstable, underpaid job to the next, never knowing the meaning of job security. Diverse examples could be cited: work in the 'informal economy', 'flexible' employment, temporary or involuntary part-time work (performed in particular by the younger generations, regardless of educational level). Work in the technology sector potentially generates situations of dependency and exploitation, creating a 'cyber-proletariat' (Huws, 2003).

Of course, not all these forms of work are necessarily precarious. Flexible employment, for instance, may be a lifestyle option or be associated with highly skilled work, with continuous learning processes or scarce skills which provide strong negotiating 
power. But that is not usually the case. In call centres, as we show, a number of negative traits associated with such forms of work emerge, particularly as viewed by the workers themselves: computer-controlled performance, enforced task flexibility, use of temporary employment in response to fluctuating demand, outsourcing and sub-contracting and limited ability to influence working conditions.

Portugal and Brazil endured decades of dictatorship during the 20th century and experienced major state intervention in the labour market, with widespread restrictions on workers' organizations. In Portugal, the 'European social model' has raised expectations among the working class in respect of living standards, particularly after the country joined the EU in 1986. Reduced working hours, longer vacations, improved social security systems and public services. The application of Community Labour Laws in areas such as health and safety, working conditions, gender equality, non-discrimination and workers' rights to information and consultation is another consequence. Nevertheless, the Portuguese employment system is still marked by low productivity, low wages, intensive labour, low levels of education and skills and poor employment quality. Since the crisis of 2008 and the imposition of austerity measures, such features have been exacerbated (Costa, 2012).

It is possible to identify five main modalities of precarious employment: fixed-term contracts, dependent self-employment, involuntary part-time work, temporary work and state-induced precariousness (Estanque and Costa, 2012; Soeiro, 2015).

Fixed-term contracts should by law be utilized only in exceptional circumstances, where the standard, open-ended or permanent contract is not possible. But they are often used outside the established legal rules and applied to jobs of a permanent nature. The socalled recibos verdes (green receipts) are documents typically linked to self-employment, which historically has played a substantial role in Southern European countries. But false self-employment has become a pervasive problem in Portugal, involving a covert relationship of legal dependency. This mechanism deprives workers of sickness or unemployment benefits, maternity allowances, leave entitlements and protection in the event of dismissal. The 63/2013 law which defined situations of false self-employment created the conditions for the 'establishment of mechanisms to fight the misuse of services contracts in subordinate work relationships'. This was a regulatory watershed in the fight against precariousness in Portugal. It also made a major difference for call centre workers, who often find themselves in situations involving false self-employment. Involuntary parttime work is less common in Portugal than in other European countries. Temporary agency work establishes a triangular relationship between the agency, the worker and the hiring company. Although advocates argue that this is a modern form of 'human resources' management that is especially suited to the particularities of the flexible economy, most workers tend to feel that temporary work is a constraint rather than a choice which enhances their autonomy. State-driven precariousness includes traineeships and contratos de emprego inserção (employment and integration contracts) which involve alternation between successive jobs and training, with no formal employment relationship, or in government programmes where the unemployed are made to work in return for subsidies but without any regular wages or the rights that are expected to come with work contracts.

Brazil went through a 'developmentalist' period from the 1930s to the late 1970s, with intense urbanization, population growth and late industrialization, together with state 
intervention in the labour market and the imposition in 1943 of the Consolidação das Leis do Trabalho (Consolidation of Labour Laws). Although the aim was to bring employment stability, half of the workers still had no social or labour protection. The 1980 s brought an opening up to the international market, with vast changes in the labour market, privatization of public services and a weakening of trade union rights. In the same decade, Brazil's fiscal crisis and the bankruptcy of a number of companies contributed to increasing informal labour in the country. In the 1990s, the Brazilian economy was fully opened to foreign trade and financial capital. Changes in the labour market, with declining industrial employment and increased employment in the service sector, did not prevent the expansion of the informal labour market. Informal work did not decline until the governments of Lula da Silva's (2003-2010), when on average 2.1 million formal jobs per year were created.

In Brazil, a number of atypical varieties of employment can also be identified, designed to evade or modify the 'standard contracts' associated with the social security system: in other words, to escape the formal process of wage compensation protected by the state and the mechanisms of collective bargaining. Atypical employment is designed to reduce costs and increase a company's power to hire and fire its workers, 'doing away with permanent commitments and employee-related costs' (Krein, 2013: 169).

Although millions of jobs were formalized during the 'Lula era', in 2011, outsourced workers made up a quarter of the formal labour market (DIEESE/CUT, 2011). Informality and atypical employment modalities are still pervasive, including a variety of fixed-term and temporary contracts, seasonal contracts for agricultural activities, works contracts, casual work and first job contracts. Atypical employment can be divided into five groups: occasional or temporary contracts and seasonal work, temporary and first job contracts which reduce costs and facilitate dismissals, special contracts to integrate vulnerable groups (young workers or the physically disabled), volunteer work and fixed-term government contracts (Krein, 2013: 176-177).

As in Portugal, Brazilian call centre operators are familiar with more than one of these modalities of employment. Súmula 331 (Statement 331) restricted outsourcing to services unrelated to the core activities of companies. In call centres, for instance, the kinds of work performed by operators are considered core activities, which means they cannot be sub-contracted by temporary work agencies. A new draft law which awaits parliamentary approval seeks to regulate such workers, stipulating that their weekly working hours should not exceed 36, including two uninterrupted daily breaks, without loss of wages. The proposed law thus explicitly prohibits any extension of working hours, unless duly justified and the parties reach an agreement 10 days in advance. The text also stipulates that changes in working hours can be made only by mutual agreement or collective bargaining.

\section{Call centres between fatalism and utopia: a brief literature review}

Literature on call centres (Batt et al., 2009; Doellgast et al., 2009; Russell, 2008) adopts opposing approaches. Some studies, which we term fatalistic, focus on negative working conditions. Other studies, which we term utopian, see scope for achievement and 
emancipation. Indeed, we are faced with 'a complex phenomenon' that '[does] not form an "industry" but rather a new form of work organization that has emerged in various industries' (Lloyd et al., 2010: 431), marked by competition and where 'the product market consists of managing service and sales transactions between provider firms and their customers' (Batt et al., 2009: 458).

Strictly, none of the literature focuses exclusively on the 'good' or the 'bad' side of call centres. Thus, in the pessimistic/realistic literature, in which call centres are seen as archetypes of the Taylorization of white-collar information work (Taylor and Bain, 1999), there is scope to endow jobs with 'strengthening institutional and regulatory frameworks, increasing the organizing capacity of trade unions, and creating an environment that seriously challenges many employers' current approaches' (Lloyd et al., 2010: 463). Likewise, in the optimistic/emancipatory literature, the obstacles related to work in call centres are also reported, such as difficulties with trade union organization, excessive pressure on wages, institutional fragmentation (Batt et al., 2009: 455; 459), as well as some aspects related to the 'Taylorized model of work design: low capital requirements, high mobility and often easily rationalized task content' (Doellgast et al., 2009: 350).

Several comparative studies (Batt et al., 2009; Doellgast, 2012; Doellgast et al., 2009, 2016; Holman et al., 2007; Holst, 2008) suggest, moreover, that we are far from scenarios of full convergence as well as total divergence, especially since legal frameworks, labour relations systems, collective bargaining instruments, labour force skills or the power of trade union actors are never fully convergent or divergent. Hence, one cannot properly speak of a 'transnational labour regime'. In our view, such a regime does not exist even for 'core' labour activities and is even more difficult to delineate in the case of 'peripheral' activities such as those that call centres seem to reflect (Doellgast et al., 2009: 353).

It is therefore important to undertake national studies to explore the different forms that the call centre 'labour process' can take, examining such factors as the conditions and forms of work organization, educational levels, wages, degree of worker autonomy, type of work contract and working hours. Call centre work often involves low wages, flexible hours, poor working conditions, high job turnover, mental fatigue, exhaustion (Lloyd et al., 2010: 458, 463), elimination of idle time between tasks, with increased work speed and output (Durand, 2004). It may involve skilled labour but is not usually considered as knowledge work (Russell, 2006: 199), which in part can be explained by the fact that 'skills' seem to be relativized by managerial control or business strategy (Russell and Thite, 2008: 617), with the incorporation of some of the main principles of Taylorism in the way that work is organized. Thus, operators do not tend to pursue a career in telemarketing, given that they do not last long on the job. Consequently, call centre companies do not offer promotion opportunities (Antunes and Braga, 2009; Braga, 2014; Lloyd et al., 2010: 452).

This 'disposable' nature of labour inevitably interferes with the dynamics of interaction in the social space of work and therefore with collective identification processes (Veloso, 2007). As Burawoy (1979) pointed out, in the Fordist system, the factory space allowed the workers themselves to provide an explanation for their consent to exploitation and to participate in a game of rewards. However, under post-Fordism, 'a system of 
permanent pedagogy decouples learning games from reward games', since apparent rewards are 'false carrots' (Sallaz, 2015: 28). This means that there is less space for commitment through incentives, but rather a maximization of the 'sense of unease' as a way to motivate new hires. But in the multinational corporation studied by Sallaz, this only worked for some people, as many left their jobs quickly, 'while even those who do master the game of call control eventually realize that their efforts go unrewarded and they too depart'. However, although he rejects the direct control hypothesis as a pathology of post-Fordism and recognizes the existence of informal norms that regulate the labour process (opening the way to a 'permanent pedagogy as a form of normative outsourcing', based on indirect, 'normative outsourcing'), a certain ambiguity remains. Even if the system does not oppress, it does not attract either and can fail in the absence of control and pressure. This has unfavourable implications for both occupational fulfilment and motivation.

Conversely, the utopian vision points to practices of emancipation and labour dignity. It suggests that advanced information technologies with highly automated work processes may reduce the routines of work through 'multi-channel' technologies based on 'a variety of ways in which workers can interact with customers, including voice, email, fax, web enablement, Voice over Internet Protocol (VOIP), media blending and electronic customer relationship management' (Batt et al., 2009: 466). This may enhance creativity and skills, enabling professionalism 'from below', enabling employees to defend rights that they 'consider intrinsic to their professional identities' and creating 'a base of potential recruits who could be mobilized by a movement, such as a trade union' in order to foster a shared identity and a congruence of goals (Vaidyanathan, 2012: 213214). This may give rise to collective strategies to gain recognition and professional emancipation, underpinned by 'institutional supports for work-place democracy and for the maintenance or extension of encompassing collective bargaining' (Doellgast, 2012: $\mathrm{x})$. Unionization could bring more democracy in call centres, more satisfaction at work and greater motivation. Trade unions can also help to expand the protections of externalized workers. In a recent study that gathers equivalent wage data and information on externalization practices from 10 companies in a diversity of countries, Doellgast et al. (2016) emphasized that 'unions and works councils placed the highest strategic priority on opposing or reversing externalization in those cases characterized both by large differences in labour costs between internal and external labour and by high ease of exiting internal employment' (pp. 2-3). But everything depends, as Doellgast (2012) warns, on the institutional framework in each country (p. 216).

We aim to contribute to these debates, specifically with regard to the subjective perceptions of call centre operators ('subjectivities from below') in two Portuguese-speaking countries that have not previously been compared on this topic. In itself, the comparison poses a challenge: given the unequal economic dynamics of the two countries (growth in Brazil, crisis in Portugal) and the equally distinct social contexts. Our empirical study is intended to show, however, that good economic conditions are not automatically converted into social improvements at work. The various items analysed to compare work activity in call centres (education and training, the task-skill relationship, safety versus insecurity at work, degree of autonomy, wages, working time arrangements, social interaction, job satisfaction, career fulfilment, motivation, trade union involvement) show, in 
both call centres, more obstacles than supports. As such, call centre work seems to be better placed in a framework of trends of precarization in contemporary work.

Like any other work activity, working in call centres cannot close the door to hope. As mentioned above, comparative literature does not focus exclusively on pessimistic or optimistic scenarios. However, we are working on the following hypothesis: if optimism exists, it is no more than a 'modest optimism'. Operators (located at the base of the company hierarchy) are confronted with a 'top-down' management discourse based on a supposed horizontal community between collaborators that only exists at the theoretical level. The existence of very good dynamics of interaction among co-workers is only one way of disguising pessimism. And even when operators recognize the emancipatory role of trade unions (especially in the Brazilian case), some scepticism persists as to their effectiveness. In this sense, trade unionism is more of a symbolic reference than a strategic focus.

The main aim of our own research - described more extensively by Costa (2016) was to capture the perceptions of call centre operators regarding their work processes. The research consisted mainly of semi-structured interviews (preceded by exploratory interviews) and surveys of call centre operators in two companies located in two mediumsized cities (with a population of around 100,000 in Portugal and 170,000 in Brazil). A total of 12 interviews were conducted in Portugal between May and July 2013, 8 of which were semi-structured and 4 of an exploratory nature. The same overall number of interviews (three exploratory, nine semi-structured) was conducted in Brazil between October and December of the same year. Interviewees were randomly selected, and interviewees were scheduled directly with operators when they left the company after their working hours. At that time, they were invited to collaborate in the study. The interview script was divided into four groups of questions:

- Socio-economic characteristics. Personal and employment history and expectations;

- Socio-occupational characteristics. A mapping of occupational circumstances marked by precariousness, fragmentation and flexibility, the aim being, in this case, to establish a connection between a telemarketing operator's work and the new socio-occupational dynamics generated by global capitalism;

- Health and work environment. Addressing the issue of the quality of the work environment as portrayed by the company to its employees while also attempting to determine the health level of this type of work and its impact on the lives of workers;

- Involvement in trade union activities. The aim was to understand the relationship between workers and their trade union and to analyse the union's specific impact on their lives.

The interviews were complemented by an online survey (LimeSurvey) of operators in both countries. More specifically, 490 email messages were sent out to operators in Portugal and 570 in Brazil. In both cases, the operators' email addresses were previously obtained outside each call centre. The sample population comprised 700 to 800 operators in each country. While a minimum of 248 to 260 would be the number of recommended responses, despite a guarantee of anonymity (ensured through the use of pseudonyms), 
many respondents (like many of the interviewees) evinced a 'culture of fear' (Silva, 2012) caused by the possibility of losing their jobs. Thus, 160 responses were obtained in Portugal (33\%) and 145 in Brazil (26\%), which can be considered reasonable. Some studies based on online questionnaire surveys tell us that the number of responses tends to vary according to the survey source and that institutional contact information carries more weight than personal contact. According to such studies, a response rate of approximately 10 percent can be considered satisfactory (Bryman and Cramer, 2003; Mathers et al., 2009). Although it would be desirable to work with a more representative sample, our findings reinforce the content of the interviews and allow us to project scenarios based on the case studies.

We develop the following argument: work in call centres does not generate processes of continuous organizational identification, not only because operators face interrupted employment trajectories but also because they are particularly vulnerable to cognitive tensions between personal projects and occupational achievements. We therefore confront subjective perceptions marked by forms of pessimism (realism!), since what operators do does not necessarily correspond to what they would like to do and, especially, to the working conditions they would like to have.

\section{The telecommunications sector}

To understand the telecommunications sector, it must be viewed in the context of the changes that have taken place within the capitalist system since the 1970s and of the emergence of the post-Fordist model. Neo-Taylorism, or Toyotism, has added a new component to the machinery of production restructuring in the world of work in general and in the telecommunications sector in particular. It has brought the intensification of work, task routinization, excessive control over workers, daily moral harassment of operators by their superiors (through verbal threats and the constant fear of dismissal), casualization and the emergence of a new sort of competitive individualism among workers. This despite the fact that Toyotism was premised on the theoretical assumption that an integrated work relationship would be possible thanks to quality circles and workplace cooperation practices. Paradoxical as it may seem, the Taylorist model of administration is undergoing a readjustment to today's capitalist labour relations and that comeback is very much present in the area of telecommunications both in Portugal and Brazil.

One should note, however, that call centre work plays only a peripheral role in the telecommunications sector, which makes it more prone to precarious conditions. The originality of call centre companies resides in their ability to provide telemarketing services by integrating information and communication technologies (ICTs) and human resources in the processing and administration of telephone data with customers seeking to gain access to a particular type of service. It is therefore just a part of a broader division of the labour process. Moreover, in a variety of sectors such as electricity, gas and tourism, telemarketing - the combined use of informatics and telecommunications improves marketing tasks carried out by operators who answer (inbound) calls to provide support to customers or make (outbound) calls to advertise products. These activities are performed by telephone, although occasionally video call centres are used instead. Each 
work station consists of a computer and a headset, which the entire networking group of operators can share (Roque, 2009). This allows for customer-company interaction; that is, a work process whereby production and total quality are computerized (Wolff, 1998) and the work environment is organized along the rational lines of scientific work (Buscatto, 2002; Lechat and Delaunay, 2003).

The process of privatization of telecommunications companies was oriented towards a productive restructuring through downsizing (rationalization) of companies' operational management, a trend in which call centres acquired increasing relevance. That implied a degradation of previous working conditions in terms of wages and social benefits. The imperative to reduce production costs and to increase flexibility, under the slogan 'improving provision and quality of services', has deepened precarious labour relations in the sector. With privatization, the sector benefitted from the 'gift' of the growth in the number of job opportunities but at the expense of outsourced companies. In this process, dimensions of competition emerge: 'between internal and subcontracting call centres, and ... among subcontractors for clients' (Holst, 2008: 30).

In Portugal, the largest state-owned telecommunications company started the privatization process in 1995. In Brazil, call centres were set up in telemarketing centres after 1990 and gained strength from 1998, with the privatization of Telecomunicações Brasileiras S.A. (Telebrás). In general terms, the number of call centres has increased both in Portugal and Brazil. According to the Associação Portuguesa dos Contact Centers (APCC, 2016), in Portugal, there are an estimated 80,000 workers in call centres (corresponding to around $1 \%$ of total employment), which is more than the number of doctors, lawyers or university teachers (Visão, 2 June 2016). In Brazil, it is estimated that over 1.4 million people work in call centres (Braga, 2014: 34).

The specificity of call centres in terms of precarious work is reflected in the standardization of work in conjunction with rules intended to shape behaviour and impose workoriented discipline. There are tight restrictions with regard to eating, smoking, chatting, making or receiving personal calls while at work and leaving one's work station. In some companies, a formal request may even be needed for toilet visits.

\section{The two call centres}

In an allusion to the crisis that hit Europe and Portugal in particular, in contrast to Brazil's somewhat brighter economic situation (despite the instability that plagued Dilma Rousseff's presidency), we have named the two call centres we studied Triste Fado (CCTF) and El Dorado (CCED). They were chosen not only because each work environment was typical of its broader economic and historical context but also because both were integrated in cities of approximate size.

We explain the main topics derived from the perceptions of the operators. The data collected yielded three sets of issues. The first has to do with education and training, working conditions and the organization of work. Some of the topics covered in this set of questions were the fit between the workers' education and prior training and the tasks they performed in the call centre, job insecurity, workplace autonomy, income and working hours. A second set bears directly on the work environment: how it was perceived, as well as the dynamics of interaction or the degree of job satisfaction. The third set of 
issues relates to involvement in trade union activities and is primarily concerned with perceptions regarding the role played by the union in terms of protecting rights, offering job stability and obtaining higher wages.

In Tables 1 and 2, we summarize some of the key similarities and differences between the two call centres.

Table I. Some similarities between the two call centres.

Job turnover, though higher in Portugal

Lack of autonomy in the production process (defining working hours and hours worked)

Low wages (but lower in Brazil)

Very good interaction among co-workers (to a certain extent, also with management in the Brazilian case)

High union membership (especially in Brazil), but scepticism regarding union effectiveness

Work perceived as a major factor in operators' lives

A clear undervaluation of the workforce, in the wake of privatization and outsourcing

Physical and psychological stress (more apparent in Portugal)

Table 2. Some differences between the two call centres.

\begin{tabular}{|c|c|c|}
\hline & CCTF & CCED \\
\hline Type of work & $\begin{array}{l}\text { Inbound (76\%), outbound } \\
(24 \%)\end{array}$ & $\begin{array}{l}\text { Outbound (60\%), inbound } \\
(40 \%)\end{array}$ \\
\hline Gender distribution & Equal & Women: $59 \%$, men $37 \%$ \\
\hline Main age group & $26-34$ & $18-25$ \\
\hline $\begin{array}{l}\text { Working time } \\
\text { arrangements }\end{array}$ & $\begin{array}{l}\text { Part-time and full-time, } \\
\text { average } 33 \text { hours }\end{array}$ & $\begin{array}{l}\text { Mostly part-time; average } 25 \\
\text { hours }\end{array}$ \\
\hline Education & $54 \%$ had attended university & $20 \%$ had attended university \\
\hline Skill/job match & $\begin{array}{l}55 \% \text { think education and } \\
\text { training are not adequate } \\
\text { (70\% in case of graduates) }\end{array}$ & $\begin{array}{l}44 \% \text { believe that they have } \\
\text { the right skills }\end{array}$ \\
\hline Union membership & $\begin{array}{l}24 \% \text { members; } 56 \% \text { non- } \\
\text { members; } 20 \% \text { no answer }\end{array}$ & $\begin{array}{l}47 \% \text { members; } 15 \% \text { non- } \\
\text { members; } 38 \% \text { no answer }\end{array}$ \\
\hline $\begin{array}{l}\text { Occupational } \\
\text { fulfilment }\end{array}$ & $\begin{array}{l}\text { Low for } 53 \% ; 20 \% \text { definitely } \\
\text { unfulfilled }\end{array}$ & $\begin{array}{l}\text { Low for } 38 \% \text {, but } 62 \% \text { are } \\
\text { dissatisfied with work and } \\
\text { working conditions }\end{array}$ \\
\hline Perception of work & $\begin{array}{l}\text { A viable alternative when job } \\
\text { prospects are bleak, not a } \\
\text { means to embark on a career }\end{array}$ & $\begin{array}{l}\text { A source of compensation, } \\
\text { despite dissatisfaction with } \\
\text { work conditions }\end{array}$ \\
\hline $\begin{array}{l}\text { Pursuing a career (in } \\
\text { telecommunications) }\end{array}$ & $61 \%$ negative; only $14 \%$ likely & $34 \%$ negative; $36.5 \%$ likely \\
\hline
\end{tabular}

\section{Education and training, working conditions and the organization of work}

At CCTF (where the majority of operators are between 26 and 34 years old), 54 percent had attended university (36\% of them had completed a bachelor's degree and 13\% a 
master's degree), whereas at CCED (where the majority of operators are between 18 and 25 years old) only 20 percent had attended university (among these, 15\% had completed bachelor's degree). A high proportion of operators thought that their education and prior training did not prepare them for the kind of work performed in the call centres. This was especially noticeable at $\mathrm{CCTF}$, with 55 percent of operators mentioning such inadequacy, but the complaint was even more striking among university graduates $(36 \%$ of the operators), in which case the proportion rose to 70 percent. This means (especially at CCTF) that operators perform tasks below their skills, for which they are overqualified. It seems that in the context of high unemployment, highly skilled people take these jobs as a last resource. Although 37 percent of operators at CCED in Brazil also considered their training unsuited to the work they do, it must be pointed out that, unlike their Portuguese counterparts, 44 percent of these respondents claimed to possess the right skills. This can be explained because the number of operators that have completed university graduation is considerably lower (only $15 \%$ ).

Second, job insecurity was pervasive. Over the past 3 years, 56 percent of operators at CCTF had held at least one other job, 20 percent had changed jobs twice and 9 percent had done so three times. At CCED, 41 percent had held a different job, 25 percent had changed jobs twice and 11 percent had changed jobs three times. A small degree of stability existed in Brazil, as 19 percent of respondents had held the same occupation for the past 3 years. However, the strong presence of short-term contracts and part-time work is frequently used by employers in both call centres as a way to manage labour in a flexible manner, adjusting it according to production peaks and market needs and also as a way to set a generally lower pay scale. Thus, the idea of a career as operators does not make much sense (especially in CCTF).

Third, in both call centres, the operators enjoyed very limited or almost no autonomy. It was the management/supervisors who defined working hours (in $51 \%$ of cases at CCTF and 58\% at CCED). The same applied to the monitoring of hours worked, which for the most part was effected by management $(68 \%$ of cases at CCTF) or upon login (43\% at CCED).

Income reflected these last two aspects. Although different kinds of work, such as inbound or outbound activities, could mean different kinds of pay (especially given that outbound work could supplement a worker's salary if it resulted in higher sales), wages tended to be low. Thus, in Portugal (where the national minimum monthly wage is $€ 557$ ), 43 percent of operators earned between $€ 500$ and 700 and 33 percent earned under $€ 500$, whereas in Brazil (where the national minimum wage is 937 Reais), the average salary at CCED was 600 Reais (just over $€ 200$ ).

Finally, it was also possible to work longer hours, especially in Portugal. There, operators worked an average of 30.3 hours a week (part-time), although 42 percent of them came close to 40 hours or even more, which means that they worked longer hours to meet targets. The following testimonies (referred to by pseudonyms) give a general picture of the situation with regard to working hours:

Yes, I often come in early. I start at $1 \mathrm{pm}$ but I come at eleven in the morning ... There are things that you just cannot do during normal hours, like calling Activations to check your sales figures. If you do it during working hours you'll be using time that you could use to make sales, but pretty much no one else does that, also you do not get paid for this in particular, but in the end 
it pays off because it makes sales more effective. On the last Saturday of every month we always come to work ... These hours are crucial to complete our sales. If you do the maths I end up working more than 40 hours a week. If you do the maths, one extra hour per day amounts to five more hours at the end of the week, and if you work six hours on a Saturday that's 12 extra hours every month. (Virginia, outbound operator at CCTF, April 2013)

At CCED, on the other hand, only 23 percent worked longer hours, and almost 60 percent had never done so. This may be linked to the fact that turnover was lower among these employees, which in turn led to greater routinization in terms of working hours:

I don't often put in extra hours. Except when there is some pending issue with the parent company, so they ask you to stay a bit longer and you get overtime pay. Since I 'log off' at noon, when there is high customer traffic, it may happen that I have to stay on until 2 or $2: 20 \mathrm{pm}$. On such occasions they ask you to stay for an extra two hours, paid at a 75 percent supplement. (André, inbound operator at CCED, August 2013)

\section{Working environment: and the dynamics of interaction}

The way in which work was perceived provided us with information on how operators invested what they did with meaning. By and large, 24 percent of respondents at CCTF described their work as monotonous and routine while also mentioning (particularly in the case of inbound operators) being closely monitored with a view to reducing average answering time. Moreover, in almost 70 percent of cases employees were pressured to meet targets:

It is both individual and collective control. It is individual because it is I who answers the calls. And it is also collective because I am part of a team that is accountable to a supervisor and the team is supposed to come up with results. (João, inbound operator at CCTF, May 2013)

A somewhat similar situation obtained at CCED, where individualization was rampant (all corporate rhetoric about teamwork notwithstanding), even if 29 percent of operators said that there was harmony in the workplace:

You end up lapsing into a routine, even though customers vary a lot. Sometimes a cheery customer will raise your spirits, or a nervous customer will get you all stressed out, or you get an annoying customer who will make you feel down. (André, inbound operator at CCED, August 2013)

The dynamics of interaction were another important component of a process of social identification in the workplace (Veloso, 2007), which to a certain extent might help compensate for the kind of dreariness described in the previous section. Thus, relationships with co-workers were viewed as very positive at both CCTF (76\%) and CCED (62\%):

My relationship with co-workers is good and there is no competition among us, none whatsoever, as there are no performance levels to achieve. (João, inbound operator at CCTF, May 2013)

I speak with my colleagues a lot when I have questions, mostly with the ones sitting next to me, because it always takes a while when you call for assistance. (Mariana, inbound operator at CCTF, June 2013) 
In theory at least, the previous point leads to another key issue: job satisfaction as it relates to occupational fulfilment. While it is true that the dynamics of interaction among co-workers may be useful if you want to keep things going, they are no guarantee of fulfilment. In fact, there was little $(51 \%)$ or no $(18 \%)$ fulfilment for 69 percent of Portuguese respondents, who accordingly saw work as an alternative or an escape:

No, I'm not satisfied, not by a long shot. Besides, there is no type of psychological support, which we should have. I mean, there is no form of compensation mechanism for the way in which this job wears you out, and the way I see it, this could easily be done, since it shouldn't be too costly for the company to raise salaries a bit, improve working conditions, etc. Everybody would benefit from a good working environment and organization, and the company would hardly have anything to lose. (João, inbound operator at CCTF, May 2013)

Similarly, although claiming to have a good relationship with management, 60 percent of the Brazilian operators working at CCED showed dissatisfaction with their working conditions, a fact that translated into low motivation levels:

If I were satisfied I wouldn't be looking for something better in this very company. So no, I'm not satisfied. Because I want a higher salary and a better job...! I still want to accomplish new things in this company, I want to achieve more, which is what I always do in life. (Inbound operator at CCED, August 2013)

\section{Involvement in trade union activities}

In contrast to individualization, collective action is a way of claiming labour rights and raising public awareness of the types of problems some occupations are faced with and a way of generating 'employee resistance' (Bain and Taylor, 2000). Membership in the traditional structures of worker representation - namely, trade unions - thus merits attention. In Portugal, it is particularly difficult to organize young people and precarious workers, which can be explained by factors related to the deregulation of labour market and to the fact that employment of these groups is predominantly in low union density sectors (Costa, 2015; Estanque et al., 2015). Membership or the mere presence of a trade union in the workplace is understood by managers' as a threat to the functioning of the company (Louçã, 2014: 91).

The Sindicato dos Trabalhadores de Call-Center (Call Centre Workers Union) was established only in April 2014 and launched an online petition addressed to the members of Parliament. Under the title 'Call centre work is an occupation causing rapid burn-out' (Sindicato dos Trabalhadores de Call-Center, 2014), this was first and foremost an attempt to draw attention to the fact that call centre work has not been recognized as a distinct occupation, and that there is therefore a legal vacuum. At CCTF, 24 percent of operators said that they were registered union members, which is perhaps surprising, both because that number is above the national average for unionization (about 19\%) and because union activism as such has little presence among precarious workers in Portugal.

By contrast, in Brazil, trade unionism within call centres is more consolidated. Despite their political inexperience, the 'telemarketing operators turned to unions for support with respect to their labour demands'. Especially, through the Sindicato dos Trabalhadores em Telemarketing (Union of Telemarketing Workers, Sintratel), it was possible to address 
not only the issue of wages but also the 'broader issues of human rights and homophobia in the workplace' following the 'social movement unionism model that works in collaboration with other social movements to build a sense of solidarity among the union, workers and diverse racial, ethnic and gay communities' (Braga, 2016: 153-154). This might explain the high number of unionized workers at CCED, where 47 percent of operators were members; this is even higher than the Ministry of Labour estimate of 32 percent unionization in call centres in Brazil.

But there is a difference between 'being a member' and 'feeling the power' of trade unions. Hence, a significant proportion (46\%) of CCTF operators viewed the union's actions as inadequate. Although 31 percent of operators viewed union action as positive with regard to job security, better pay and working conditions, 46 percent were unsure, as they neither agreed nor disagreed that the union had a relevant role in this respect.

At CCED, only 33 percent - a significant number nevertheless - viewed the union as inadequate, while a quarter of respondents considered that the union was essential and that conditions would be much worse without it, and nearly 40 percent thought that they benefitted from joining the union.

\section{Conclusion}

Our article has addressed two interrelated issues. Its point of departure was that current transformations in the world of work show a tendency towards precarious, fragmented and flexible labour relations at a global level and in call centre work in particular. We sought to demonstrate that, despite the existence of multiple modalities of precariousness, there is no questioning the continuing centrality of work as a social category. Our analysis of two call centres (one in a Western European country affected by a long economic crisis and another in an expanding Latin American country) showed that work remains crucial to the life of workers.

Call centre work is perceived subjectively by the operators of both call centres as a temporary activity rather than as a stable career, which supports the fatalist rather than to optimistic literature on this sector. In the Brazilian case, the idea of occupational progression is limited to the formalization of informal employment and not to an elevation of levels of citizenship. Similarly, in the Portuguese case, there is far to go in terms of the occupational regulation of call centre work.

It is possible to list a number of conclusions based on the two case studies. First, the call centres tend to recruit workers (both male and female) who are young, qualified, but mostly precarious. Second, Call centre work is diverse but demonstrates a return to the Taylorist model of job control. This model is marked by a corporate type of discourse which, although valuing teamwork, in practice uses an individualizing logic aimed at pressing each worker to meet pre-set targets. Third, by the same token, the combined effect of the 'inclusive' rhetoric and of the widespread use of ICTS has not ended the old divisions and hierarchies in the context of work, even if the illusion has been created that workers are now collaborators rather than mere employees still almost devoid of autonomy. Fourth, although clearly evident in the sector, union activity faces significant obstacles and is viewed sceptically by many workers. This raises the need to rethink the forms of action and collective bargaining of call centre workers. Fifth, not only from trade 
unionism 'outside' but also from the world of work 'inside', the emancipatory potential of the organizations and movements of precarious workers might help in the future to build another democracy at work (Hyman, 2016), which for the moment is still only incipient both at CCTF and CCED.

In short, the larger realities reflected by the two call centres, CCTF and CCED, are not radically different. It may be said, by way of conclusion, that the Portuguese situation looks sombre in the context of our case study, in the wake of the world economic crisis. As for Brazil, it is clear that the job satisfaction and sense of professional fulfilment that are supposedly part and parcel of the 'El Dorado' are just a façade, and that the economic, social and emotional contexts where these operators carry out their work share far more similarities than might be anticipated.

Since November 2015, Portugal has been ruled by a minority Socialist government, with parliamentary support from two parties to its left, whereas in April 2016, Brazil witnessed the start of the impeachment process against Dilma Rousseff's government, leading to her replacement by the right-wing Michel Temer in August 2016. But although these changes in the political context (with important economic consequences) in both countries may suggest a 'role reversal' between 'Triste Fado' and 'El Dorado', the truth is that both call centres seem still a long way from raising the bar of dignity at work.

\section{Acknowledgements}

The authors thank the anonymous referees and the editor for their insightful comments and suggestions concerning the earlier versions of this article.

\section{Funding}

The author(s) received no financial support for the research, authorship and/or publication of this article.

\section{References}

Antunes R (1999) Adeus ao Trabalho? Ensaios sobre as metamorfoses e a centralidade do mundo do trabalho. Campinas, Brazil: Cortez.

Antunes R and Braga R (eds) (2009) Infoproletários. São Paulo, Brazil: Boitempo.

APCC (2016) Estudo de caracterização e benchmarking. Lisbon: APCC.

Bain P and Taylor P (2000) Entrapped by the 'electronic panopticon'? Worker resistance in the call centre. New Technology, Work and Employment 15(1): 2-18.

Batt R, Holman DM and Holtgrewe U (2009) The globalization of service work: Comparative institutional perspectives on call centers (Introduction to a Special Issue). Industrial \& Labor Relations Review 62(4): 453-488.

Braga R (2014) Precariado e sindicalismo no Brasil contemporâneo: Um olhar a partir da indústria do call centre. Revista Crítica De Ciências Sociais 103: 25-52.

Braga R (2016) On Standing's A Precariat Charter: Confronting the precaritisation of labour in Brazil and Portugal. Global Labour Journal 7(2): 148-159.

Bryman A and Cramer D (2003) Análise de Coleta de dados em ciências sociais: Introdução as técnicas Utilizando o SPSS para Windows. Oeiras: Celta.

Burawoy M (1979) Manufacturing Consent: Changes in the Labor Process Under Monopoly Capitalism. Chicago, IL: University of Chicago Press. 
Buscatto M (2002) Les centres d'appels, usines modernes? Les rationalizations paradoxales de la relation téléphonique. Revue Sociologie Du Travail 44(1): 99-117.

Cingolani P (2005) La Précarité. Paris: PUF.

Costa ES (2016) A hegemonia do capital nas atlanticidades telecomunicativas: $O$ trabalho e o social na era da informação. Rio de Janeiro: Multifoco.

Costa HA (2012) From Europe as a model to Europe as austerity: The impact of the crisis on Portuguese trade unions. Transfer 18(4): 397-410.

Costa HA (2015) Le syndicalisme portugais et l'austerité: Entre la force des protestations et la fragilité des alliances. Relations Industrielles/industrial Relations 70(2): 262-284.

DIEESE/CUT (2011) Terceirização e Desenvolvimento: Uma conta que não fecha. São Paulo: DIEESE.

Doellgast V (2012) Disintegrating Democracy at Work: Labor Unions and the Future of Good Jobs in the Service Economy. Ithaca, NY: Cornell University Press.

Doellgast V, Batt R and Sørensen OH (2009) Introduction: Institutional change and labour market segmentation in European call centres. European Journal of Industrial Relations 15(4): 349-371.

Doellgast V, Sarmiento-Mirwaldt K and Benassi C (2016) Contesting firm boundaries: Institutions, cost structures, and the politics of externalization. ILR Review 69(3): 551-578.

Du Gay P (1996) Consumption and Identity at Work. London: Sage.

Durand J-P (2004) La chaîne invisible. Travailler aujourd'hui: flux tendu et servitude volontaire. Paris: Seuil.

Estanque E and Costa HA (2012) Labour relations and social movements in the 21st century. In: Erasga D (ed.) Sociological Landscapes: Theories, Realities and Trends. Rijeka: InTech/ Open Access Publishing, pp. 257-282.

Estanque E, Costa HA and Silva MC (2015) O futuro do sindicalismo na representação sociopolítica. In: Freire A (ed.) O futuro da representação política democrática. Lisbon: Nova Vega, pp. 119-142.

Hewison K (2016) Precarious work. In: Edgell S, Gottfried H and Granter E (eds) SAGE Handbook of Sociology of Work and Employment. London: Sage, pp. 428-443.

Holman D, Batt R and Holtgrewe U (2007) The Global Call Centre Report International Perspectives on Management and Employment. Ithaca, NY: ILR Press.

Holst H (2008) The political economy of trade union strategies in Austria and Germany: The Case of Call Centres. European Journal of Industrial Relations 14(1): 25-45.

Huws U (2003) The Making of a Cybertariat: Virtual Work in a Real World. New York: Monthly Review Press.

Hyman R (2016) The very idea of democracy at work. Transfer 22(1): 11-24.

Kovács I (2005) Emprego flexível em Portugal: alguns resultados de um projeto de investigação. In: Kovács I (ed.) Flexibilidade de emprego: riscos e oportunidades. Oeiras: Celta, pp. 11-53.

Krein JD (2013) As formas de contratação: flexibilidade. In: Krein JD, Celso Pereira Cardoso J, de Barros Biavaschi M and Oliveira Teixeira M (eds) Regulação do trabalho e instituições públicas. São Paulo, Brazil: Fundação Perseu Abramo, pp. 167-186.

Lechat N and Delaunay J (2003) Les centres d'appels: Un secteur en clair-obscur. Paris: L'Harmattan.

Lloyd C, Weinkopf C and Batt R (2010) Restructuring customer service: Labor market institutions and call center workers in Europe and the United States. In: Gautie J and Schmitt J (eds) Low-Wage Work in the Wealthy World. New York: Russell Sage Foundation, pp. 421-466.

Louçã JC (2014) Call Centers: Trabalho, Domesticação, Resistências. Porto: Deriva. 
Mathers N, Fox N and Hunn A (2009) Surveys and Questionnaires. Leeds: NIHR RDS for the East Midlands, Yorkshire \& the Humber.

Paugam S (2013) La disqualification sociale: Essai sur la nouvelle pauvreté. Paris: PUF.

Roque I (2009) As linhas de montagem teleoperacionais no mundo dos call centres: um retrato local numa moldura transnacional. MSc Thesis, Faculty of Economics, Coimbra.

Russell B (2006) Skill and info-service work in Australian call centres. In: Burgess J and Connell J (eds) Developments in the Call Centre Industry: Analysis, Changes and Challenges. London: Routledge, pp. 92-116.

Russell B (2008) Call centres: A decade of research. International Journal of Management Reviews 10(3): 195-219.

Russell B and Thite M (2008.) The next division of labour: Work skills in Australian and Indian call centres. Work, Employment and Society 22(4): 615-634.

Sallaz JJ (2015) Permanent pedagogy: How post-Fordist firms generate effort but not consent. Work and Occupations 42(1): 3-34.

Silva MC (2012) Vencer O Medo: Ideias Para Portugal. Lisbon: Temas e Debates.

Sindicato dos Trabalhadores de Call-Center (2014) O Trabalho em Call-Centers é uma Profissão de Desgaste Rápido! Available at: http://peticaopublica.com/pview.aspx?pi=PT74238

Soeiro J (2015) A formação do precariado: transformações no trabalho e mobilizações de precários em Portugal. PhD Thesis, Faculty of Economics, Coimbra.

Standing G (2009) Work after Globalization. Cheltenham: Edward Elgar.

Standing G (2011) The Precariat: The New Dangerous Class. London: Bloomsbury.

Taylor P and Bain P (1999) An assembly line in the head: Work and employee relations in the call centre. Industrial Relations Journal 30: 101-117.

Vaidyanathan B (2012) Professionalism 'from below': The mobilization potential of Indian call centres. Work, Employment and Society 26(2): 211-227.

Veloso L (2007) Empresas, Identidades e Processos de Identificação. Porto: Editora da Universidade do Porto.

Wolff S (1998) Informatização do trabalho e reificação: Uma análise à luz dos Programas de Qualidade Total. Campinas, Brazil: UNICAMP.

\section{Author biographies}

Hermes Augusto Costa is a Professor at the Faculty of Economics and Researcher at the Centre for Social Studies, University of Coimbra, Portugal.

Elizardo Scarpati Costa is an Assistant Professor at the Institute of Human and Information Sciences and the Postgraduate Programme in Law, Federal University of Rio Grande, Brazil. 